天然ガス・電力部門にみる EEC 条約 100 条 $\mathrm{A}$ の適用事例 $\mathrm{EC}$ のエネルギー政策の新展開

\title{
児玉 昌 己(純心女子短期大学)
}

はじめに

市場統合の完成期限を今年末に控え，ECの市場統合に向けた努力も各政策 領域において一段と熱を帯びている。実際，280余の EC 法の制定の目標のう ち，1992年初期の段階ですでに220あまりの法案が採択されている。

また1991年12月のオランダで開催された政府間会議において， EC 加盟国は 1992年以降を視野に入れる通貨統合, 政治統合を目指し, EC 設立諸条約の再 度の本格改正となる欧州同盟条約草案の承認に合意し，92年 2 月各国政府は正 式調印した。現在各国で批准作業が進行中である。エネルギー分野についても， この条約の草案の段階で，独立した条文が挿入される動きさえみられた。

この欧州同盟条約は，それまでの ECの統合を経済的なものから政治的なも のへと質的に変化させる動きであり，まさに「ポスト 92 年」という EC 政治の 新たな段階への発展と考えることができる。

この事態を目前にして, 単一欧州議定書 (Single European Act) が市場統合 に果たしつつある意義の評価を行っておく必要がある。とくに，単一欧州議定 書については，1987年 7 月に発効し，その後の EC の政治に多大な影響を及ぼ している。が, その初期においては，あの著名な EC 法学者ペスカトール元 EC 裁判所判事の Common Market Law Reviewの論文『単一欧州議定書に 
天然ガス・電力部門にみる EEC 条約100条 Aの適用事例（児玉）

関する若干の見解』に見られるように，必ずしも，十分な評価が与えられてい なかったのである。

本稿では，単一欧州議定書が市場統合の促進に大きく貢献しているという基 本的な認識の下に，エネルギー分野，とりわけ天然ガス・電力部門に焦点を合 わせ，「送電網による電力通過に関する理事会命令案」と「大規模システムを 通した天然ガスの通過に関する理事会命令案」という 2 つの法案の成立過程を 捕捉する。

それは第 1 にエネルギー分野においては，この 2 つの法案において，ECの 市場統合努力が象徵的に現われているからだけでなく，2 法案が電力と天然ガ スの市場を構造的に変革し，さらにはこれまでの EC のエネルギー政策に大き

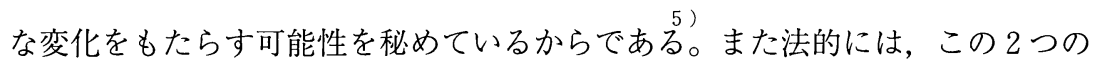
法案が, 単一欧州議定書で新たに導入された「協力手続き」に基づく EEC 条 約100条 A を法的根拠にしており，「特定多数決」という特異な意思決定のメカ ニズムのなかで，一部の加盟国の強力な反対を押し切り成立しているという事 実があるからである。つまり，この法制度をもって，およそ従来の制度では考 えられなかった EC の政策決定状況が，エネルギー分野でも起っているのであ る。第 3 に，エネルギー分野で市場統合を推進する条文を法的根拠にする関連 法案が今後も出されてくる可能性が高いからである。

以下, 次の要領で本稿を進めていく。1）従来の EC エネルギー政策の概略, 2 ）「市場統合」の登場とエネルギー部門への影響，3）電力と天然ガスの 2 つの理事会命令（指令）案の内容，4）協力手続きと EEC 条約 100 条 Aにおけ る EC 主要機関の役割，5）2 法案の立法過程と加盟国・ヨーロッパ議会の対 応，6）結論

1) 日本経済新聞1992年 1 月21日。内容については, Sixth Report of the Commission to the Council and the European Parliament concerning the implementation of the White Paper 
on the completion of the Internal Market COM (91) 237 final 19 June 1991.

2 ）欧州同盟条約草案のエネルギー関係条文についてはルクセンブルク草案では Title XII で明 記された。Draft Treay on the European Union: Agence Europe; Documents, No. 1722/ 1723. 5 July 1991. ただし交渉の最終段階のオランダ案（同 Documents, No. 1750/51, 13 December 1991）でこれは削除された。決定された同条約の全文は Agence Europe; Documents, No. 1759/60. 7 February 1992. 参照。

3 ) Pierre Pescatore, "Some Remarks on the Single European Act", Common Market Law Review, Vol. 24. No. 11987 参照

4 ）単一欧州議定書の政治学サイドからの分析，評価は田中俊郎「単一欧州議定書と域内市場」 『国際問題』1988年 7 月号，および日本国際政治学会編『国際政治: 政治統合に向かう EC』日 本国際政治学会，1991年第94号で先鞭が加えられているが，この報告はその成果を受けたもの である。

5 ) 例えば, Royal Institute of International Affairs and Science Policy Research Unit, A Sing le European Market in Energy; Joint Report of the Energy and Environmental Prgramme. (RIIA 1989) L. Hancher, "Towards a Free Market for Energy ?: A legal perspective." Energy Policy, April 1990. "Conflicting Objectives in European Energy Policy," in C. Crouch and D. Marquand ed., The Politics of 1992; Beyond Single European Market (Baisil Blackwell 1991)など最近のこの変化についての研究がある。

6 ）マーストリヒト条約は「協力手続き」をさらに発展させた「調停手続き（Conciliation Procedure)」(189条 b ) を導入し, 単一欧洲議定書で導入したばかりの 100 条 a を削除し, こ の189条 b の適用を受けるものと EEC 条約を改正している。

\section{第 1 章＼cjkstart市場統合と EC のエネルギー政策の関連}

\section{1 ）旧来の EC のエネルギー政策}

1985年に出され，それ以降の EC 政治を決定付けていく域内市場白書では工 ネルギー部門は，どのように位置付けられていたのであろうか。まずこの点を 理解しておく必要がある。が，その前に若干旧来の ECのエネルギー政策につ いて言及しておく必要があろう。

EC のエネルギー政策については，「アルルの女」であるという評価がある。 これは，あの著名なビゼーの作品からとられたもので，フランスのエネルギー 業界関係者が ECのエネルギー政策を挪揄した表現である。つまり，誰もが 「アルルの女」（=ECのエネルギー政策）について聞いたことがあるが，その 
天然ガス・電力部門にみる $\mathrm{EEC}$ 条約 100 条 $\mathrm{A}$ の適用事例（児玉）

実，その実際を知るものは誰もいないというもので，言及される割に内容にそ しいECのエネルギー政策を表現したものである。

実際，ECはその設立から石炭鉄鋼共同体 (ECSC), 原子力共同体 (EAEC) というように，エネルギーを主体とする共同体を構築して来たにも かかわらず，全般的に，目立った成果を収めて来たとはいい難いのである。

もとより, 石油備蓄の ECレベルでの義務化, エネルギーの価格・需給関係 の情報入手と, その情報を活用した需給関係の予測や加盟国の関係企業の利害 の調整による過剩設備の削減などでは, 一定の成果を収めている。

しかし，共通エネルギー政策の推進については，EC 内部，外部の要因が作 用し， ECが困難を抱えてきたことも指摘できる。つまり外部要因としては， $\mathrm{EC}$ の加盟国が例えば，イギリスは北海石油，フランスは原子力，オランダは 天然ガスというように，そのエネルギー資源の分布や，それを基本にした政策 において極めて多様であること，エネルギー情勢そのものが，対外的な，つま り EC が直接には関知しない外部要因によって左右され, 不可測な側面を常に 内包していることが指摘できる。また内部要因としては，1957年の調印以降長 年にわたり $\mathrm{EEC}$ 条約では共通エネルギー政策に関するなんら明確な規定もな く, また超国家的な政策決定システムをもち, 意思決定過程が複雑で, 時間を 要するという EC 固有の制度上の問題を抱えていたことを指摘できる。

これに加え，エネルギーの政策の実行者は第 1 義的に加盟国であり，EC と してできることは，例えば，中期目標として加盟国が守るべき「エネルギー目 標」を定め, 加盟国がエネルギー源毎に10年のタイム・スパンで達成目標を設 定し，それに向けて加盟国の努力を求める，つまり ECが望むエネルギー状況 に誘導するというように，かなり限定されていたということができる。

ちなみに「エネルギー目標」は最近のものとしては，1986年に採択された

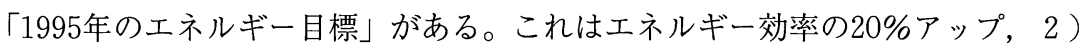
石油輸入の抑制，（エネルギー消費の 3 分の 1 以下） 3 ）天然ガスおよび固形 燃料の市場占有率の維持, 4 ) 石油・ガス発電の抑制，5）発電にしめる原子 
エネルギーの役割の強化——が合意されている。

ところが，こうした状況を一転させ，ECのエネルギー政策に大きな影響を 及ぼし，ECのこの「95年のエネルギー目標」と矛盾する動きが現われている。 これが1985年に公表され，後に単一欧州議定書となって EC の政治の表舞台に 登場する「域内市場白書」であり，市場統合の動きである。

\section{2 ）市場統合のエネルギー政策の関連}

域内市場達成の動きはそれではエネルギー分野にどのような影響を及ぼした のだろうか。

まず初めに，域内市場白書では，エネルギー部門は，白書がリストアップし た，市場統合の範囲として指摘した分野の外に置かれていた事実を指摘する必 要がある。実際，エネルギー分野については，EC 委員会第17総局（エネル ギー総局）もその機関誌の中で自ら認めるように，域内市場白書では直接的に はなんら言及されていなかったのである。つまり，その時点において，エネル ギー部門はいまた加盟国の国家主権の範疇に置かれる分野と考えられていたこ とを指摘できる。それにもかかわらず，その後の展開を見ていくと，この白書 の影響は，エネルギー分野においても大きな役割を果たしたといえる。つまり， これ以降，エネルギー分野においても，市場の開放に向けた動きが加速するこ とになる。

この過程を時系列的に主要な動きの中に見てみよう。

1987年 6 月 2 日, EC 委員会エネルギー担当委員ニック・モザールは理事会 で，域内エネルギー市場を阻害する要因を「総ざらい」し，1992年末までにそ れを除去するための諸措置を明らかにするという意図を言明し，理事会での支 持を得た。1988年 5 月 2 日には『域内エネルギー市場』と題する報告書を作成 し，ECのエネルギー分野における「非」統合的な現状を分析した。そして， 潜在的な障害を石炭, 石油, 天然ガス, 原子力の分野でそれぞれ指摘した。 ま た1989年に 3 月には，エネルギー分野において「分割ヨーロッパ」の状態で生 
天然ガス・電力部門にみる EEC 条約100条 Aの適用事例（児玉）

じるコストをEC の GDP の0.5一1.0\%と算定する文書を発表した。つまり， 大文字の「市場統合」のコンテキストにおいて, エネルギー部門も取り扱う姿 勢を明らかにした。

その後，EC 委員会第17総局は初めてこの具体的施策の実現を図るため法案 を策定し，1989年10月30日のエネルギー理事会に提出した。EC 委員会は，エ ネルギー部門での市場統合のための諸措置の法制化にこうして着手したのであ る。EC 委員会が理事会に提出した主な法案は次のものであった。

1 ）送電網による電力通過に関する理事会命令案

2 ）大規模システムを通した天然ガスの通過に関する理事会命令案

3 ）産業上の最終ユーザー向け電力とガス価格の透明化の改善のための EC 手 続に関する理事会規則亲

このように，電力とガス部門が中心になっていた。つまり，不透明で，競争 を阻害する要因となっている電力とガスの価格の透明化の促進がうたわれる一 方で，エネルギー貿易の促進を図る目的で，電力とガスの 2 法案が出された。

以下この電力と天然ガスの通過に関する 2 法案についてその内容, 法的根拠, 立法過程について見ていきたい。

1 ) Pierre Maillet, "A la recherch de l'ntrouvable politique énergétique européenne", Revue $d u$ marché commun, no 321. novembre 1988) p. 504

2) EC 委員会の石油精製部門における利害調整機能については, 拙稿「ECの石油精製産業の 危機と EC 委員会の役割」日本 EC 学会編『欧州統合の現段階』日本 EC 学会年報第 6 号1986 年参照。

3） ECのエネルギー政策の概要については, 拙稿「エネルギー政策」金丸輝男編著『EC一欧 州統合の現在』所収, 創元社1990年第 2 版参照。EC のエネルギー政策進展の阻害要因につい ては拙稿「ECの市場統合とエネルギー政策の新動向」行政管理研究センター編『EC 対外政 策の新展開』(財)行政管理研究センター発行1991年 3 月参照。

4 ）石油危機を経て，1970年代後半にその策定が始まっている。拙稿「ECの市場統合とエネル ギー政策の新動向」『前掲書』100頁参照。もっともこれでさえ例えば，原子力エネルギーの発 電における役割の巡り激しいデンマークからの反対があり, 数值の設定は見送られている。 
5 ）域内市場白書の内容については，佃・田中・長友『1992年 EC 市場統合』有斐閣1990年参照

6) European Commission, Energy in Europe, March 1989 p. 9. 公共調達との関連でエネルギー が対象分野としてとり上げられるのも1988年になってからのことであった。もっとも市場統合 努力が本格化し，その成果についての年次進捗報告が出るにあたってはその中で，エネルギー 分野もその中で言及されるにいたっている。例えば，第 5 次報告。Fifth Report of the Commission to the Council and the European Parliament concerning the implementation of the White Paper on the completion of the Internal Market COM (90) Final, 28 March 1990 p. 11.

7 ) Internal Energy Market COM (88) 238 final 2 May 1988. なおこれは Energy in Europe; Special Issue 1988. にも転載されている。天然ガス・電力については, 輸送と配給での競争, 価格の透明性の確保, 加盟国間の送電・送ガス網の接続, 輸出入の排他的権限の廃止が上げら れている。な㹉子力については十分な政策がとられていない。ちなみに稼動中の原子力発電 所の基数は1990年 6 月末現在でそれぞれ，フランス52，イギリス38, ドイツ 27 (旧東独 6 ), スペイン 9 , ベルギー 7 , イタリア 2 基である。

8 ）拙稿「ECの市場統合とエネルギー戦略」日本国際政治学会編『国際政治; 政治統合に向か う EC』日本国際政治学会1991年94号53頁

9 ) Draft council directive on the transit of electricity through transmission girds. Draft council directive on the transit of natural gas through the major systems. Draft council directive concerning a Community procedure to improve the transparency of gas and electricity prices charged to industrial end-users. これらは EC 委員会の，以下のいわゆるコム（COM）文書に それぞれ添付収録されている。Commission of the EC, Towards the Completion of a Single Market for Electricity, COM (89) 336 final. Towards the Completion of a Single Market for Natural Gas, COM (89) 334 final. Price Transparency for Industrial End-Users of Gas and Electricity, COM (89) 332 final.

10）またエネルギー管理技術向上のための理事会規則案（通称「Thermie計画」）Proposal for a council regulation concerning the promotion of energy technology in Europe.もあった。

\section{第 2 章 「送電網による電力通過に関する理事会命令案」と「大規模 システムを通した天然ガスの通過に関する理事会命令案」}

この $2 つ の$ 法案は，条文構成や条文の数などほぼ同一で，内容的にも非常に 明瞭な共通点がある。EC 委員会は電力と天然ガス産業をほぼパラレルのもの とみていたことの証明である。これら 2 法案の特色は, 大略次のようである。 1 ） 2 つの法案の目的は, 電力と天然ガス部門において市場競争原理を導入し, すでに一部は行われている加盟国間の電力・天然ガスの流通を，ECレベルで 
法制化し，その促進を図るということである。またその手段として，まずエネ ルギーの「通過（transit）」という概念を導入していることである。つまり，1 つ以上の EC 加盟国を「通過トランジット」し，第 3 の加盟国に電力と天然ガ スの輸送を可能にすることを ECレベルで確保することを目指している。

また，そのために，高圧送電網と大規模ガス・パイプラインという輸送手段 を所有する主要企業をリストアップし（電力は 21 社，天然ガスは 43 社），遠隔 地でエネルギーを買い付ける需要家にたいして，これらの輸送手段を開放する ことを目指している。つまり, 需要家が送電網とガス・パイプライン網を一時 的に借り受け，直接生産者から，自社の望む価格でエネルギーを購入すること を可能にするものである。言い替えれば，第 3 者に輸送手段を開放する，「第 3 者アクセス（third party access; APT サード・パーティ・アクセス)」と一般に呼 ばれる考え方に立脚した法案である。この法律により，送電網とガス・パイプ ラインの所有者は「公輸送人」(コモンキャリア; common carrier) としての役割 を果たすよう求められるというものである。

具体的には，電力や天然ガスの輸送を需要家が希望すれば，供給網を所有す る企業は，彼らと輸送条件に関し交渉を行わねばならないこと，それについて は EC 委員会および関係国に通告すること，もし交渉が，輸送余力に欠けると いった正当な理由がなく，もしくはその理由が不十分であるために一定期間内 に成立しない場合，EC 委員会が仲裁に入るか，あるいは EC 裁判所の裁定に 委ねるというものである。

これらの措置により，エネルギーの一層自由な流通を促進し，国を単位に市 場が閉鎖状況にあるエネルギー市場を開放していくということを狙っている。 つまるところ, 域内市場の達成の一環としてとらえる措置であり，エネルギー 部門における市場統合の試金石として位置付けられるものと考えることができ るのである。

この 2 法案を理解するには, 我が国と異なるヨーロッパの電力と天然ガスの 産業の多様な構造を理解しておく必要がある。ヨーロッパの場合, 例えば，天 
然ガス産業は，生産部門と輸送部門が別個の企業により担われている。ヨーロ ッパでは，この部門においては，生産から配給に至るまでの機能を一元的に支 配する企業は存在せず，天然ガスの開発・生産会社 (producer), それを輸送す る供給手段を有する企業（transporter），そして各家庭への配送を担当する配給 会社 (distributor) というように，それぞれ別個に存在しているのである。そし てそのなかでも，どちらかといえば，ガス・パイプライン網の所有者にガス・ ユニー (オランダ), ルールガス (ドイツ), ガズ・ド・フランスといった巨大 企業が存在している。

他方, 電力産業についていえば, 仏, 伊, ギリシア, アイルランドでは国営 の垂直統合的な単一の事業体が発電，輸送，配給に責任を持っている一方で， その他の加盟国では数個の民間，公営もしくは政府管轄下の企業が同様の機能 を果たしている。そしてこの両方の産業とも, 輸出入という供給面において, こうした特定の企業が法的, 実質的に優越的立場をもち, 独占的な権益を亨受 している状況にある。

EC 委員会によれば，この状況を背景にして，いまだに需要家が自己の欲す るエネルギーを「自己の望む場所と価格で選択できる」状況になく, 統合市場 の理念に反した状態であること, 電力の場合では「市場の国毎の縦割り的分 断」(compartmentalization) の除去により，エネルギー貿易を拡大し，2010年に は60一130億 ECUの経済効果を上げ得ること, 天然ガスについては, 同様に 第 3 者アクセスの措置により, 2000年には生産コスト, 経営効率の向上などで 6 億 2,500 万 ECUの経済効果をあげると試算していた。

1 )，２），3）これらの法案については拙稿「EC 市場統合とエネルギー戦略」『前揭書』57一 8 頁。電力については藤原淳一郎「EC 電気市場統合論序説」『法学政治学論究 (慶応)』第 9 号1991年参照。

4 ）例えば，オランダではガスユニー（国家が50\%の権益を保有）が自国に入ってくる天然ガス をすべて最初は同社が扱う。またガスパイプライン会社は同国の運輸, 経済両省との協定を結 
天然ガス・電力部門にみる EEC 条約100条 Aの適用事例（児玉）

ぶ必要がある。ドイッでは BEB が最大の生産開発会社で, 資本構成はドイッ・シェル, ドイ ツ・エッソの合弁である。またルールガスは独占的な輸送（transmission）会社, MEGAL (ソ連からの天然ガスを運ぶ国際パイプライン会社) と TENP（オランダ産の天然ガスを運 ぶ）のそれぞれ $50 \%$ ，51\%の権益を保有。J.P. Stern, Europe Gas Markets; Challenge and Opportunity in the 1990s (RIIA 1990) およびCOM (89) 336 final, COM (89) 334 final 参照

5 ) ヨーロッパの電力産業については, D. Finon, Opening access to european grids : In search of solid ground, Energy Policy, June 1990 p. 430. COM (89) 336 final 参照

6 ）拙稿「ECの市場統合とエネルギー戦略」『前掲書』57-8 頁

\section{第 3 章 2 法案の立法上の特色 :「協力手続き」に基づく EEC 条約 100 条 $\mathrm{A}$ の内容とその立法過程上の特色}

\section{2 法案の法形式上の特色:「協力手続き」に基づく EEC 条約100条 A} それではこの 2 法案の法形式上の特色についてみよう。

この 2 法案は，ECの基本条約の改正である単一欧州議定書で導入された 100 条 A に基づく EC 命令案（draft directive）である。すなわち，エネルギー分 野においても，域内市場の統合のための他の措置と同様の取り扱いが法的にな されているということである。つまり「協力手続き」EEC 条約第149条（単一 欧州議定書第 7 条) を必要とする EC 法案である。

エネルギー部門で， EEC 条約100条 A をその法的根拠としていることこそ， エネルギー政策，とりわけ電力と天然ガス部門での政策が市場統合に向けた全 般的流れの中に，位置付けられていることを証明するものといえる。

元来，「協力手続き」は，基本的にはヨーロッパ議会の権限拡大をはかり， 日頃指摘される「不十分な民主主義」（Democratic Deficit）の批判に答え，EC の一層の民主化をはかるために導入されたものである。が，それは，同時に市 場統合の諸措置の実行を容易にするためにも，適用されているのである。なぜ なら，ECの意思決定過程において，多くの条文で，「特定多数決」が規定さ れていたにもかかわらず，あの有名な「ルクセンブルグの妥協」以降，理事会 で全会一致が慣行化することで，特定多数決は実際には死文化していたのであ る) 
それゆえ, 単一議定書の導入を契機にして, EC は, 意思決定において, 本 来 $\mathrm{EC}$ が定めていた「特定多数決」を積極的に活用することにより，ヨーロッ パ市民から直接選挙されたヨーロッバ議会の権限を拡大し，ECが民主主義を 基礎としていないという批判に答え，同時に $\mathrm{EC}$ の長年の懸案となっていた意 思決定の遅れを是正し，これによって市場統合の実行を容易にすることを意図 したのである。EEC 条約100条A は，特定多数決を必要とする「協力手続き」 を必要とする，単一欧州議定書で新たに導入された，いくつかの重要な規定の

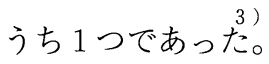

\section{2 立法過程における EEC 条約100条 A（単一欧州議定書第18条）の政治 的意味}

それでは，上記 2 法案の立法過程を理解するために，協力手続きを必要とす る EEC 条約100条 A（単一欧洲議定書第18条）の下での立法過程における主 要機関の役割を 1 ) 理事会， 2 ）ヨーロッパ議会，3）個別加盟国に限定して 概括的に述べておこう。

\section{1 ）理事会}

まずこの EEC 条約 100 条 $\mathrm{A}$ を法的根拠にする EC 命令案の場合，それまで の EEC 条約100条の時と違い，理事会は立法権限を独占できなくなったとい うことである。つまり以前は, ヨーロッパ議会に諮問した後は, 決定は理事会 が行うというものであった。第 2 に立法過程で，特定多数決が導入されている 点である。とくに，立法過程で，理事会は第 1 読会と第 2 読会か新設された。 そして第 1 読会では，「特定多数決」で「共通の立場」が採択されることが必 要となった。特定多数決とは，4大国がそれぞれ $10 ， そ の$ 他の加盟国も人口規

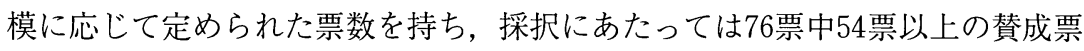
が必要となる。 また理事会は, 法案にたいして法案の修正や拒否といった異議 を唱える場合，各段階で様々な制限が置かれている。 
2 ）ヨーロッパ議会

ヨーロッパ議会の権限強化については，政策の決定にあたって，第 2 読会ま で参加するということである。単一欧州議定書以前は, EEC 条約 100 条の下で は，ヨーロッパ議会は理事会から一定の条件の下で単に「意見を徵せられる」 に止まっていた。このことを考えれば，これは，画期的であった。もともと単 一欧州議定書はヨーロッパ議会の権限拡大による EC の民主主義の強化をその 目的の 1 つにしたものであったから，これは，その方向性の反映であった。

具体的にいえば，ヨーロッパ議会は，絶対多数で，理事会が採択した「共通 の立場」を拒否することができる。これを理事会が覆すためには，全会一致が 必要となることである。つまりヨーロッパ議会があくまでも反対する法案につ いては，加盟国の 1 つをヨーロッパ議会がとりこめば，ヨーロッパ議会の意向 を通すことができるのである。

\section{3 ）個別加盟国}

次に, これを個別加盟国の側からみると, 次のような特色が見られる。理事 会が「共通の立場」を採択するにあたって，もしそれに反対の立場をとる加盟 国があれば，法案の通過を阻止するために，23票以上集めなければ，その加盟 国の意思を理事会で通すことができない。

加盟国の立場から見れば，たとえ国家的な利益の要請により，その法案に反 対であっても，その主張を通すためには他の複数の加盟国の支持を得ねばなら ない。例えば，かつては EEC 条約100条が根拠となる命令案の場合，全会一 致のため，実質的に 1 力国の反対だけで，その意思を通すことができた。これ に対し，この特定多数決をクリアーする工作に成功しない限り，加盟国はその 意思を通すことができないのである。つまり利害が限定されて, 他の複数加盟 国の支持を取り付けれない加盟国にはとって，法案採択を阻止するのが決定的 に困難となっているといえる。

まとめると, EEC 条約 100 条 A を法的根拠とする法案は, 一度上程されれば, 
理事会および加盟国にとってそれを覆す動きには厳しい制限がとられているこ と，つまり基本的には，法案の採択が容易に進むようなシステムになっている ということである。電力と天然ガスの通過法案は，こうした立法上の特色を持 つ法案であった。

以上の立法上の特色を踏まえた上で，以下では，この100条 A を法的根拠に する電力とガスの 2 法案が一体いかなる政治過程を経て採択されるにいたるの かをより具体的に見ていこう。

1) EEC 条約100条 $\mathrm{A}(1)$ は次のように規定している。

「理事会は委員会の提案に基づき，欧州議会と協力して，かつ経済社会委員会と協議の後， 特定多数決により，域内市場の確立および運営を目的とする加盟国の法律，規則および行政措 置の接近に関する措置を定める。」

2 ）金丸輝男「EEC の政決定過程における多数決方式と「一括処理」方式」『国際政治 : 国際統 合の研究』日本国際政治学会編1984年77号参照。

3 )「協力手続き」が必要とされる条項は EEC 条約の 100 条 Aの他に次のような箇所に導入され ている。 EEC 条約第 7 条（国籍に基づく差別の禁止）４9条（労働者の自由移動）, 54 条 2 項 (居住の自由)，56条 2 項（外国人の取り扱いに関する法令整備），57条 1 項および 2 項（資格 の相互認証）いずれの項目も市場統合の推進に役割を果たす事項であるが，とりわけ100条 A は域内市場の確立に直結する分野であるだけに，その影響が大きいということができる。また 注意されねばならないのは，財政，人の自由移動，ならびに被雇用者の権利に関しては，その 適用の範囲外になっているという点である。「協力手続き」の全般的な意義については，槩江 義勝「EC の政策決定の構造」日本国際政治学会編『前掲書』日本国際政治学会1991年94号, D. Lasok and J. W. Bridge, Law and Institutions of the European Communities 4 ed., (Butterworths 1987) pp. 458-461. 参照。

4) $\mathrm{EEC}$ 条約100条は「理事会は委員会の提案に基づき, 全会一致で, 共同市場の設立または運 営に直接影響を及ぼす構成国の法令および行政規則を接近させるために命令を発する。総会お よび経済社会評議会はこの命令を実施することが 1 または 2 以上の構成国の法律の改正を伴う 場合には，その命令について意見を徵せられる」と定めている。

5 ) 特定多数決における 4 大国以外の持ち票は, スペイン 8 , ベルギー, ギリシア，オランダ, ポルトガル 5, デンマーク 3, アイルランド 3, ルクセンブルク 2（EEC 条約148条 2 項）

6 ）このシステムが確立されたために，ヨーロッパ議会は，一種の「拒否権」(T.ハートレー) をもつことになった。そしてこれを背景に，ヨーロッパ議会は事前に，その意向を「共通の立 場」に取り入れるよう理事会に影響力を行使することができるのである。これにより，この 
100 条 Aのような協力手続きを必要とする EC 法案の場合, 理事会は, EC 委員会の提案の審 議，採択にあたっては，ヨーロッパ議会の要望を以前とは比較にならない程十分尊重せねばな らなくなっているのである。EC 委員会への影響についていえば，EC 委員会が提案（法案） を作成し, 理事会, ヨーロッパ議会に提出する従来の $\mathrm{EC}$ の政策決定方式と変わるところはな い。が，EC 委員会は以前は理事会での決定が全会一致であったがために，1つの加盟国が強 く反対する法案については，その法案が通る可能性は低い。したがって，その理事会への上程 をためらい，法案提出を抑制する傾向を見せる傾向にあるといわれてきた。が，単一欧州議定 書により法案が容易に阻止できる全会一致でなく，特定多数決が導入されたことで，ヨーロッ パ議会の意向を組んで，積極的に「共同体の推進者」としての本来の役割を担うことができる 法的環境を得たといえる。T.C. Hartley, The Foundation of European Community 2nd ed. (Clarendon 1988) p. 34.

7 ） EC の制度をスタティックに扱った概説書では，加盟国の理事会での意思決定に扔ける行動 様式について，これをあたかも一枚岩のものと見なす傾向があるが，最近の研究でロッジが指 摘するように，個別利害を反映して，加盟各国の立場はイシュー毎に様々である。Juliet Lodge, "EC Policymaking : institutional considerations", in J. Lodge ed., The European Community and the Challenge of the Future (Pinter 1989) p. 42.

\section{第 4 章 電力・天然ガス 2 法案の立法過程と 加盟国・ヨーロッパ議会の対応}

\section{1 法案の成立過程とその実際}

\section{1 ) 電力通過法案}

電力通過法案は次の経過を経て, EC 法として成立した。すなわち, EC 委 員会の提案（法案）を1989年 7 月 12 日委員会内で採択した。これをもとに, 理 事会では初討議が10月に行われた。その後, 経済社会委員会の意見を得で, 1990年 4 月, ヨーロッパ議会の第 1 議会へと進み，これを受けて, 修正された $\mathrm{EC}$ 委員会の提案が同年 5 月 21 日に委員会で採択されだ これにもとづき理事 会は，5月21日に「共通の立場」についての「政治的合意」という段階を経て， 「共通の立場」を採択し，第 1 読会を終えた。ヨーロッパ議会は10月10日，第 2 読会で修正付きで法案を支持, このヨーロッパ議会の修正を受け, EC 委員 会は10月 24 日提案を再検討, 再提出, 理事会はその法案を 90 年 10 月 29 日に最終 的に採択した。 
2 ) 天然ガス通過法案の成立過程は以下のようである。

$\mathrm{EC}$ 委員会は1989年 7 月 12 日に提案（法案）を採択。同年10月, 理事会での 初討議が行われた。その後, 経済社会委員会の意見が出され, 1990年 7 月11日 にヨーロッパ議会の第 1 読会へと進んだ。 $\stackrel{8}{8}$ 。 $\mathrm{EC}$ 委員会は同年 9 月 21 日, 修正した提案を委員会で採択。理事会はこれをも とに10月29日特定多数決で「共通の立場」を採択した。翌1991年 4 月17日， ヨーロッパ議会は, 技術的修正を加えて第 2 読会を終えた。その後, EC 委員 会はヨーロッパ議会の修正を受け，5月16日提案を再検討し，再提出。同月31 日，理事会は第 2 読会で，特定多数決により，この法案を最終的に採択した。 加盟国は1992年 1 月 1 日までに国内法制化を完了しなければならないことに なった。

1) OJ. C 8, 13. 1. 1990.

2) OJ. C 75, 26. 3. 1990.

3 ) OJ. C 113, 7. 5. 1990.

4) $\mathrm{COM}(90) 207$ OJ C114, 16. 6. 1990

5) $\mathrm{COM}(90) 51$

6) 正式には Council Directive of 29 October 1990 on the transit of electricity through transmission grids OJL 313/13/30 と呼ばれる。

7) OJ. C 8, 13. 1. 1990.

8) OJ. C $231,17.9 .1990$.

9) OJ. C 268, 24. 10. 1991.

10) OJ. C 129, 20.5. 1991.

11) $\mathrm{COM}(91) 166$.

12）正式には Council Directive of 31 May 1991 of the transit on natural gas through grids 90/ 296/EEC OJ L 147/37 と呼ばれる。

\section{$2 \quad 2$ 法案の立法過程における加盟国・ヨーロッパ議会の対応}

それでは，この 2 法案の立法過程で注目された点について指摘しておく必要 
天然ガス・電力部門にみる EEC 条約100条 Aの適用事例（児玉）

がある。とりわけ，加盟国とヨーロッパ議会の対応を中心にみてみたい。

1 ）加盟国の対応

注目されるべきは，2法案に対して特定の加盟国が激しく抵抗したこと，と くに天然ガス法案では，上述した「特定多数決」という意思決定の制度により， 複数の加盟国の反対が斥けられ，法案の採択へと進んだという事実である。 $\mathrm{EC}$ の理事会の意思決定過程の内部の動きは秘密性が極めて高いが, EC 理事 会の内部情報を最も豊富に提供してくれるベルギーの日刊 EC 専門紙『アジャ ンス・ヨーロッパ(Agence Europe)』などを使い, この過程を理事会の第 1 読 会を中心にみてみよう。

\section{A 電力の通過法案}

まずこの法案の成立過程で，加盟国が賛成，反対に 2 つの陣営に別れたこと である。フランスはこの法案の支持国であり，受益国であった。フランスは自 国の原子力発電所から生まれる余剰電力を，特にドイツの電力業界に輸出する ことを望んでいた。ドイツの電力業界はドイツ連邦政府からの要請により，い わゆる「世紀契約」のもとで，価格の高い国内炭の購入を要請されていたので ある。

またポルトガルはフランスからの安価な電力の輸入を望んでいた。

これにたいし，法案にためらいを示したのは，ドイツ政府とスペインであっ た。ドイツは産炭国家として，産炭地の保護という政治的要請があった。89年 段階でドイツの石炭部門への国家補助は 120 億ドイツマルクであり，EC の第 3 世界への援助総額の 4 倍であるとエネルギー担当 $\mathrm{EC}$ 委員により非難を受け ていたほどである。もしこの法案の成立により，エネルギー間の競争が促進さ れれば，国際的に見て価格競争力のないこの国の石炭産業が，窮地に立つとい う状況が起こることを恐れていた。

スペインは自国産の電力をポルトガルに輸出する意向をもっており，価格競 争力のあるフランスの余㮃電力が自国の領土を「通過」して，ポルトガルに供 給されることを国家主権を盾にして阻んでいた。この法案が採択されれば，こ 
の抵抗が無力化するのであった。

イギリスは基本的にサッチャー政権が推し進めている産業の一般的な規制緩 和の考え方があり, 反対ではなかった。1983年以降，エネルギー法で供給網に 対する「オープン・アクセス」の原則を導入していたのである。

またデンマーク, ベルギー, アイルランド, ギリシアも EC 委員会の提案を 支持していた。デンマークはイタリアへの電力の輸出（ドイツを通過）を，ま たオランダはフランスから電力の輸入（ベルギーを通過）を望んでいた）また アイルランドやギリシアは送電網が他の EC 諸国と接続されておらず，このた め, これを機会に, EC から財政援助を受け，電力の基盤整備を進めようとい う考え方が存在した。理事会ではこうした各国の立場が主張され，結局ドイッ は不満を抱えながらも，石炭部門への国家援助についての EC 委員会からの非 難に対する政治的配慮もあり，反対に回ることを抑えたのである。こうして 「共通の立場」は内部に潜在的な対立を抱えたまま，採択がなされたのである。 直接的記述を避け，極めて政治的つまり平板な表現をせざるをえない EC の 『月報 (Bulletin)』は「政治的合意」という表現でこの経緯を記述している。 これは，加盟国の不満の存在を表わすものであったといえる。

B 天然ガスの通過法案

この法案は電力法案以上に激しい抵抗を一部の加盟国に起こした。実際, 天 然ガスの通過法案は, 電力の法案と同時に1989年10月の理事会で討議が始まっ たにもかかわらず，電力の法案が最終的に決着した1990年10月29日の理事会に おいては，まだ「共通の立場」の採択の段階であった。つまり，1年を経た時 点においても，天然ガス法案はまた法案の入口の段階に止まっていた。このこ とからも，この法案に対する一部加盟国と関係業界の反対の強さを知ることが できる。

理事会の「共通の立場」の採択にあたって，反対の立場を示したのは，デン マーク, ドイツ, オランダであっだ。オランダは EC 内の最大の天然ガスの生 産国として，この法案がその利益を損なうという危機感があった。またドイッ 
天然ガス・電力部門にみる EEC 条約100条 A の適用事例（児玉）

はこの法案の対象となるガス供給会社が独占的立場を持つルールガスを含め， 29社あり，もっとも影響を受けると見ていた。

こうした国・企業の主張をまとめると，次のようになる。

1 ) ガス・パイプライン網が第 3 者に開放されれば，その管理者が供給の安 全確保などに莫大な資本投下を行っている事実を忘れ，供給の安全確保に全く 責任を負わない第 3 者が，短期的な利益を得るだけである。

2 ) 天然ガスの契約においては，20年という長期契約が交わされ，引き取り については，生産国との間で極めて厳格な契約が結ばれ，その見返りに供給の 安全が保障されるという特殊性を持っているが，こうした引き取りの条件が崩 れてしまゔ。

3 ）電力と天然ガスでは，その国際的貿易の規模と構造において相違がある。 天然ガスは電力以上に広く EC という地理的範囲を超えて，国際貿易が行われ ている。また電力と天然ガスでは供給における対外依存の程度は異なっている。 電力の場合，域内での需要は満たされているため，問題は価格に限定される。

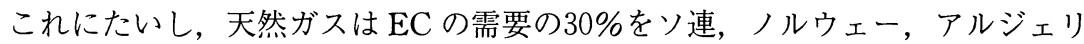
ア，リビアの域外諸国に依存している。しかるにこの法案は，国内の他の業種 が天然ガス市場に参入するのを促進し，ヨーロッパの買い手を相互に競争させ， ヨーロッパの買い手を細分化し, 結果として, 売り手である EC 域外の輸出国 の立場（バーゲニング・パワー）を強化する「自虐的法案」であると主張して いた。

実際，この法案は，第 3 者の天然ガス市場への参入を促進し，既存企業の既 得権益を喪失させる可能性を秘めており，関係企業はこれをもっとも恐れてい た。例えば, ドイツ最大の化学会社 BASF の子会社, ビンテルシャル （Wintershall）はソ連との合弁で，ドイツから東欧に至る新規ガス・パイプライ ンの建設を予定している。そして同社が自ら低価格で調達するソ連産ガスを， この天然ガスの通過法をもとにして，リストアップされたガス供給会社を通じ てルールガスに依頼すれば，ドイッ西部にある BASF の化学工場に輸送する 
ことができるのである。ガス・パイプライン網の独占的所有者であるルールガ スは，これが実質的にコモン・キャリッジ制度と同じ結果をもたらし，同社は 単に輸送を扱うだけの「請負人」に後退するとして, 反対していた。

ドイツ，オランダ政府は，こうした関係業界の圧力と業界の利害の保護の必 要性を背景に, 理事会の各段階で法案に反対したのである。この態度は，この 法案の法的根拠 $\mathrm{EEC}$ 条約 100 条 A そのものにも向けられた。特にオランダは, すでにみたように，基本的には法案が上程されれば，成立に向けて動いていく 法的メカニズムを内包しているのであり, 理事会の 1 読会以前の 90 年 5 月の理 事会で EEC 条約 100 条 A がこの法案の法的根拠となることに強く反対したの である。

しかし特定多数決では，すでに述べたように，採択を阻止するためには，76 票中 23 票を必要とする。が, ドイツ，オランダ，デンマークは10, 5, 3 の18 票である。つまり 5 票差でその法案阻止の意思が通らなかったのである。例え ば 5 票をもつギリシアを反対陣営に取り込めば，廃案にできたのであるが， 3 国は理事会での「共通の立場」という法案の入口の段階で敗れたのである。こ れ以降，91年 5 月の理事会（ルクセンブルク議長国アレックス・ボードリー議 長）の第 2 読会における特定多数決まで，ドイツなどは反対を続けていくが, その意思は理事会で通ることはなかった。一度, 法案が上程され, 加盟国がそ の法案を「共通の立場」の段階で阻止できなければ，すでに見たように，ヨー ロッパ議会が理事会で採択した「共通の立場」を拒否でもしない限り，その加 盟国はもう法案を阻止できないシステムになっていた。

2) ヨーロッパ議会の対応

それでは 2 法案へのヨーロッパ議会の対応はどうであったのだろうか。 まず注目すべきことは，ヨーロッパ議会の取り組みである。ヨーロッパ議会 は，両法案においても，協力手続きのメカニズムを活かし，EC 委員会の提案 を練り直させているのである。またヨーロッパ議会の第 2 読会においても, 法 案について修正を加えた。この過程で, ヨーロッパ議会は議会内委員会を総動 
天然ガス・電力部門にみる $\mathrm{EEC}$ 条約100条 $\mathrm{A}$ の適用事例（児玉）

員して動いている。例えば，天然ガスの場合，エネルギー問題を所管とする 「エネルギー・研究・技術委員会（CERT）」はもとより，「経済通貨問題・産 業政策委員会」,「運輸・観光委員会」,「環境・公共保健・消費者保護委員会」 にその意見を求めたのである。また所管のエネルギー・研究・技術委員会は関 係する業界団体，消費者団体などを招き，公聴会を開くなど積極的に取り組ん だ。

結果的に，ヨーロッパ議会は，市場開放についての大枠については同意しつ つも, EC 委員会がコストを優先し, 環境保護や供給の安定確保への配慮が十 分考慮されていないという観点に立って, 雨法案とも技術的なものも含め, 法 案への一部修正を織り込んだのである。

ヨーロッパ議会については，1989年の直接選挙で環境保護派が34議席（518 議席中）を占める大躍進もあり，とりわけ，「エネルギー・研究・技術委員会 (現定員22名)」は環境保護派が副委員長のポストを抑えるなどして, 彼らの積 極的な意見が強く反映されているのである。

まとめれば，2法案とも，ヨーロッパ議会は法案に供給の安全確保と, 環境 の保全を求める修正を提案し，EC 委員会はこれを入れた形での提案を理事会 に出した。つまり「協力手続き」という武器で，議会はその影響力を EC の立 法過程のなかで如何なく発揮したのである。

1 ） D. Finon, ibid., p. 430. 余剰原子力の輸出を意図する当時の EC 理事会議長国のフランスと, そしてフランスの電力輸入に自国の利益を見出すポルトガルの出身エネルギー担当 $\mathrm{EC}$ 委員カ ルドソ・クーニャが，同時期一体となって電力の国際貿易の促進を打ち出す大きな役割を果た したとフィノンは指摘している。なおフランスの電力生産にしめる原子力の役割は 80 年の 23.5 から88年には70\%に達している。Nuclear Industries in the Community: the Nuclear Power Station Design and Construction Industry and Completion of the European Single Market. COM (89) 347 final., 7 Feb. 1990. p. 26.

2) Agence Europe, 7 June 1989.

3 ）もっともイギリスのブリティッシュ・ガスにみられる開放政策は，限定されたものであり， 
十分成果を収めているわけではないという見方もある。

4 ) Royal Institute of International Affairs and Science Policy Research Unit, ibid., p. 26.

5 ) Bull. EC10-1990. p. 72.

6 ) Agence Europe, 29/30, October 1990. p. 7

7 ), 8 ) Report on the Proposal from the Commission to the Council for directive on the transit of natural gas through the major system, European Parliament: Session Documents, Document A3-161/90 pp. 15-16.

9 ）ガス貿易の国際的規模からすれば，「域内市場という言葉は奇妙な言葉」だとさえ一部の業 界関係者は語っていた。“The European Gas Market Before and After” by J. Haye ed., The Single European Act; the Business Implications for Downstream Oil and Gas (Institutue of Petroleum 1989) 参照

10）Petroleum Economist，（日本語版）1989年 4 月 142 頁

11）この法案はとりあえず，天然ガスの通過を義務づけ，ECレベルで天然ガスの国際輸入を制 度化したものである。が, 特定の輸送企業をリストアップし，それらに義務を負わせるという 点では, コモン・キャリッジ制度の方向性を内包したものであって, ビンテルシャルの場合の ようなケースが恒常化すると，独占的な立場を亨受して来た輸送会社は既存の利権と市場を㓏 かされることになる。こうした点を関係企業は, 恐れたのである。『天然ガス』1991．2．20頁

12) Agence Europe, 19 May 1990 p. 11.

13）例えば，「単一天然ガス市場の目的は，より多くの収益性と供給の安全確保することにある」 に「環境上の適合性」という文言を挿入し，環境の保護に留意すべきことを求めている。電力 についても基本的に同様であった。European Parliament: Session Documents, Document A3-161/90 ibid., p. 3.

14）エネルギー研究・技術委員会の副委員長は環境保護派が占めていて, 最近ではフランスの同 副委員長を初めとするメンバーがフランスの電力価格の透明性の欠如, エレクトリシテ・ド . フランス社の電力部門における独占的地位の乱用を理由に, EEC 条約 $90,93,169$ 条違反とし て EC 裁判所に提訴するよう EC 委員会に求め, もし EC 委員会が動かねば, ヨーロッバ議会 が行うように働きかけるとしていた。Agence Europe, 17 October 1991 p. 12.

\section{結論}

以上，それまでは国家の産業と経済に直結する国家戦略的な部門として，国 家主権の直接的な保護下にあり，それゆえ，あまり手が付けられて来なかった エネルギー部門，とりわけ電力と天然ガスの部門において，市場統合の動きと 連動した形で，市場開放が進みつつある。 
天然ガス・電力部門にみる EEC 条約100条Aの適用事例（児玉）

この過程ですでに見たように，ドイツなど一部の加盟国の強い反対を押し切 り，その意思を拒否しながら進んでいるという事実は，驚くべきものである。 ECの主要国ドイツは，電力でも反対を封じ込まれ，天然ガスでもまた公然と 特定多数決で押し切られ，その立場を斥けられ，理事会でその意思を反映させ ることができなかったのである。これはまさに，単一欧州議定書の導入と協力

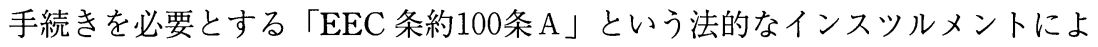
って初めて可能となった状況であり，それなしでは，こうした法案は採択が不 可能であったといえるであろう。このことを考慮する時, 単一欧州議定書の役 割は, もともと域内市場白書に拈いて触れられることのなかったこのエネル ギー分野においても，極めて大きな役割を果たしているといえよう。

その意味では, 単一欧州議定書は連邦主義者としての理想の高みから見て 「後退」であり「偽善的」であり, EEC 条約 100 条 A は「法案作成の形式 (legal drafting) としての最悪のもの」とする, ペスカトール元判事の否定的評 価をはるかに超えて，市場統合に向けた動きを加速しているといえるであろう。 とりわけ, ヨーロッパ議会は, 従来予算権限など徐々に権限拡大を図ってきた が，単一欧州議定書で協力手続きが導入されたことにより，ECの立法過程， そして政治過程全般に，一段と大きな役割を果たしてきており，今後もその影 響力は不可逆的に強まるものといえる。

エネルギー市場の開放の動きに戻っていえば，これによって問題が解決した わけではない。むしろ問題は今後に残されているように思える。つまり, 競争 の導入により, 大口需要家獲得のための值引き競争が起き, その㱀寄せが一般 のユーザーへの料金の值上げとなって跳ね返ってくるのではないか，また競争 の激化が供給の安全確保への関心を低下させ，それを損なうのではないかとい うョーロッパ議会レベルでも示された懸念がある。さらには第 3 者への供給手 段の開放は，エネルギー資源間の競争を促進させ，国際競争力においてほとん ど勝負がついている石炭部門の一層の縮小を招き，この部門を抱えるドイツや 関係企業の困難を生じさせる可能性も高い。すでに石炭は EC のエネルギーで 
のシェアを大幅に落とし，92年以降10年間で $\mathrm{EC}$ の石炭生产は70\%に相当する 1 億トンの削減が予測されている。

これらは，今後 $\mathrm{EC}$ のネルギー分野においては，供給の安全確保を重視し た政策と，市場統合のイデオロギーとして出てきたフリー・マーケット思想に 立脚した政策の間の対立，矛盾を一層深刻なものにしていくであろう。実際， すでにその矛盾は現われており，「1995年の EC のエネルギー目標」が定めて いた石炭の市場占有率の維持は困難になっている。また同じく，この「目標」 が揭げていた天然ガス発電の抑制政策も，価格競争力と，環境適合性を理由に， 天然ガスがむしろ有望な資源として再評価されることにより，策定後，わずか 4 年にして，その撤廃を余儀なくされたのである。これらがエネルギー専門家 が「1995」VS「1992」と表現するECのエネルギー政策の矛盾の一部である。 今後,「市場が全てを決する」というフリー・マーケット思想に立脚した競 争の導入を推し進める過程で，加盟国の独自の資源分布とエネルギーの生産供 給構造を念頭に打いた，供給の安全確保や環境保護をどこまで確保できるかと いう極めて困難な問題を引き起こすものと思われ，EC 委員会がその両者のバ ランスをいかにしてとっていくかという問題を残している。

いずれにせよ，こうした問題を孕みつつも，電力，天然ガスの分野で第 3 者 アクセスによる供給独占の打破という形で，市場開放が始まりつつある。そし てこうした法制度の確立と並行して， EC 加盟国の電力・天然ガスの送電網や 基幹パイプラインの完全接続を目指した動きも本格化するなど，エネルギー分 野で，新しい局面がすでに生まれつつある。

この過程で, EC の諸機関とりわけ EC 委員会とヨーロッパ議会は, EC の エネルギー政策において「アルルの女」と挪揄された状況を払拭し，明確なプ レゼンスと役割を EC の政治の中に確立しつつあるといえよう。

最後に，国家主権の壁の中からエネルギー分野まで引き出され始めたとすれ ば，EC と加盟国の権限関係はさらに EC の側に傾きつつあるといえるであろ j。 
1) P. Pescatore, ibid., p. 11. p. 16.もっとも，熱烈なヨーロッパ統合論者である同氏はこの〈意 外な〉展開を喜んでいるかもしれない。なおハンシャーは100条 Aのエネルギー部門での適用 について，EC 委員会がその機関に供与された権限を超えて多用し，加盟国が EC 裁判所にそ の legality（適法性）を争う事態が続出する危険性さえ指摘している。Hansher, ibid., p. 234.

2) 伝統的な EC 委員会一理事会の対話にヨーロッパ議会が加わること, とりわけ, EC 委員会 での修正や理事会の第 1 読会で, ヨーロッパ議会の修正が採り上げられる比率が高まることは, 国家レベルでの「議院」に比較できる程だと述べている。Richard Corbett, Testing the New Procedures; the European Pariament's First Experiences with its New 'Single Act' Powers, Journal of Common Market Studies Vol. XXVII, no. 4 June 1989. p. 362.

3 ) Report drawn up on behalf of the Committee on Energy, Research and Technology on the internal market 28 April 1989 (European Parliament Drcument A2-158/89) p. 8.

4 ) Royal Institute of International Affairs and Science Policy Research Unit, ibid., p. 32.

5 ) Ibid. p. 49.

6 ） 1989 年後半から EC で討議がはじまっている運輸，電気通信，電力・ガスなどの分野を包括 的に取り扱う計画である。トランス・ユーロピアン・ネットワーク (Trans-European Networks）の計画の一環として，天然ガスではイタリア本土一サルディニア（イタリア）— コルシカ（フランス）と 2 国 3 地域を結ぶ天然ガス・パイプラインの敷設（15億 ECUの費用 が予定), 1993年完成予定のギリシアの天然ガスパイプラインの敷設, フランスからスペイン を経てポルトガルに供給するガス・パイプラインの敷設計画，イギリスーアイルランド間の海 底ガス・パイプラインの敷設（EC はその全費用の約 3 分の 1 を負担する予定）とそのフラン スへの接続などが推進されつつある。European Report No. 1663 March 23, 1991 また電力に ついては, フランスースペイン一ポルトガル間の既存の送電網の相互接続の強化, アイルラン ドーイギリス間の，イタリアーギリシア間の送電網の相互接続などが計画されている。COM (89) 643 final., Draft Council Resolution on the Trans-European Networks pp. 9-10.こうし た計画は EC 委員会の地域政策担当総局 (DG16) とエネルギー総局（DG17）間の連係をも 深めさせる効果を果たしている。また最近ヨーロッパ・エネルギー憲章でこのネットワークを 旧ソ連・東欧にまで拡大しょうという動きもある。拙稿「エネルギーからみた EC の対ソ連・ 東欧関係とヨーロッパ・エネルギー憲章」行政管理研究センター調查研究部編『EC 統合と東 欧政策』行政管理研究センター1992年 3 月参照。

\section{付 記}

本稿は1991年11月10日の第12回日本 EC 学会 (同志社大学) での研究報告を 基にし，その後の情勢を踏まえ加筆，修正したものである。資料等は EC 委員 会, 同駐日代表部広報部, 同志社大学及び西南学院大学の EC 資料センター (EDC) にお世話になりました。記して感謝申し上げます。（1992. 4. 23） 


\section{質疑応答}

田中会員(慶応大学) 天然ガスと電力通過法案の政策決定過程の分析が, EEC 条約100条 A の適用ということでなされたが，EEC 100条 Aについては， $\mathrm{EC}$ 委員会の修正は，ヨーロッパ議会の第 1 読会後が，もっとも頻繁におこな われ，重要なものと考えられる。その意味では EEC 100 条 Aには規定されて いないが，この点を使用された協力手続に関するハートレーを基にするフロー チャートに加えるのがよくはないか。

児玉 確かに御指摘の通り，その傾向はあると思われます。大変貴重な示唆 であり，今後の研究の参考にさせてもらいたい。

中村会員(大阪産業大学) 航空運輸の分野では「カボタージュ」が行われて いるが，エネルギー産業ではどういう状況なのか。

児玉 航空運輸の分野におけるカボタージュの概念については知識がない。 ただ市場を開放してエネルギー貿易の促進を図るという方向が EC のエネル ギーの「トランジット」2 法案の基礎となっている。

司会者(コメント） カボタージュの概念は，児玉会員の報告では，エネル ギー分野では否定されているという主旨の報告が行われている。つまり報告で は，「カボタージュ」という相互主義は否定され，ヨーロッパレベルでの市場 開放が相互に進んでいる。

清水会員(駒沢大学) 付表の天然ガスのフローの数字の総計は一致しないが。 また天然ガスに関する価格は。

児玉 数值についてはオリジナルがそうなっている。 天然ガス価格に関しては，残念ながら十分資料を持ち合わせていない。 